Research Article

Animal Genetics

\title{
Comparative chromosomal mapping of microsatellite repeats reveals divergent patterns of accumulation in 12 Siluridae (Teleostei: Siluriformes) species
}

Sukhonthip Ditcharoen ${ }^{1 *}$, Francisco de Menezes Cavalcante Sassi ${ }^{2 *}$, Luiz Antonio Carlos Bertollo ${ }^{2}$, Wagner Franco Molina ${ }^{3}$ (D), Thomas Liehr ${ }^{4}$, Pasakorn Saenjundaeng ${ }^{5}$, Alongklod Tanomtong ${ }^{1}$, Weerayuth Supiwong $^{5}$, Chatmongkon Suwannapoom ${ }^{6}$ and Marcelo de Bello Cioffi ${ }^{2}$

${ }^{1}$ Khon Kaen University, Faculty of Science, Department of Biology, Toxic Substances in Livestock and Aquatic Animals Research Group, Muang, Khon Kaen, Thailand.

${ }^{2}$ Universidade Federal de São Carlos (UFSCar), Departamento de Genética e Evolução, São Carlos, SP, Brazil.

${ }^{3}$ Universidade Federal do Rio Grande do Norte (UFRN), Centro de Biociências, Departamento de Biologia Celular e Genética, Natal, RN, Brazil.

${ }^{4}$ University Hospital Jena, Institute of Human Genetics, Jena, Germany.

${ }^{5}$ Khon Kaen University, Faculty of Applied Science and Engineering, Nong Khai Campus, Muang, Nong Khai, Thailand.

${ }^{6}$ University of Phayao, School of Agriculture and Natural Resources, Department of Fishery, Muang Phayao, Thailand.

\begin{abstract}
The freshwater family Siluridae occurs in Eurasia and is especially speciose in South and Southeast Asia, representing an important aquaculture and fishery targets. However, despite the restricted cytogenetic data, a high diploid number variation (from $2 n=40$ to 92 ) characterizes this fish group. Considering the large genomic divergence among its species, silurid genomes have experienced an enormous diversification throughout their evolutionary history. Here, we aim to investigate the chromosomal distribution of several microsatellite repeats in 12 Siluridae species and infer about their possible roles in the karyotype evolution that occurred in this group. Our results indicate divergent patterns of microsatellite distribution and accumulation among the analyzed species. Indeed, they are especially present in significant chromosome locations, such as the centromeric and telomeric regions, precisely the ones associated with several kinds of chromosomal rearrangements. Our data provide pieces of evidence that repetitive DNAs played a direct role in fostering the chromosomal differentiation and biodiversity in this fish family.
\end{abstract}

Keywords: Repetitive DNAs; fish, chromosomal rearrangements, karyotype evolution.

Received: March 28, 2020; Accepted: September 03, 2020.

\section{Introduction}

The freshwater family Siluridae ranges in Eurasia, but containing the higher number of species in South and Southeast Asia (Bornbusch, 1995; Kottelat, 2013), with 103 recognized species (Fricke et al., 2019), thus representing important aquaculture and fishery targets. Silurid species show a significant size diversity, such as Silurus glanis, reaching over $300 \mathrm{~kg}$ in weight and $2 \mathrm{~m}$ in size (Linhart et al., 2002) and Silurus soldatovi, that reaches $400 \mathrm{~kg}$ in weight and up to $4 \mathrm{~m}$ in size (Berg, 1964), while others are much

Send correspondence to Marcelo de Bello Cioffi. Universidade Federal de São Carlos (UFSCar), Departamento de Genética e Evolução, Rodovia Washington Luiz Km. 235, C.P. 676, São Carlos, SP, 13565-905, Brazil. E-mail: mbcioffi@ufscar.br

"These authors contributed equally to this work. smaller, being used as ornamental fishes (Ng et al., 1994; Chapman et al., 1997; Ng and Ng, 1998;) or biological indicators ( $\mathrm{Ng}$ and Lim, 1992; $\mathrm{Ng}$ and $\mathrm{Ng}, 1998$ ). The monophyletic status of Siluridae is supported and confirmed by both morphological and molecular data (Bornbusch, 1995; Hardman, 2005), and, altough their phylogenetic position was doubtful for many years (Bornbusch, 1995; Hardman, 2005; Sullivan et al., 2006), a recentl study placed this family in the root of taxon Siluroidea (Kappas et al., 2016).

Cytogenetical studies in Siluridae are still mostly restricted to conventional cytogenetic protocols, with some exceptions where the molecular cytogenetic approach has been used (Verma et al., 2011; Ditcharoen et al., 2019). However, despite the restricted cytogenetic data, a high $2 \mathrm{n}$ variation characterizes this fish group, ranging from 40 in Silurichthys 
phaiosoma (Ditcharoen et al., 2019) to 92 in Kryptopterus cryptopterus (Donsakul and Magtoon, 1996) and Kryptopterus geminus (Ditcharoen et al., 2019). It is also known that Phalacronotus is the only genus that maintains the diploid number conservation with $2 \mathrm{n}=64$ in all analyzed species, while other genera in this family display a substantial variation (Ditcharoen et al., 2019). On the mapping of highly repetitive sequences, the high $2 \mathrm{n}$ variation also appears to be followed by a large variation of ribosomal DNAs loci among silurid species (Ditcharoen et al., 2019). Considering the extensive genomic reorganization, as revealed by CGH (comparative genomic hybridization), it is evident that silurid genomes have experienced an enormous diversification throughout their evolutionary history (Ditcharoen et al., 2019).

Microsatellites are repetitive DNA sequences, varying from one to six nucleotides, found in genomes of all eukaryotic organisms (Cioffi and Bertollo, 2012; López-Flores and Garrido Ramos, 2012). These repeats can also be associated with coding regions of structural genes and between other repetitive sequences (Tautz and Renz, 1984), contributing to the functional and structural organization of the genome (Schueler et al., 2001). Fish genomes usually have microsatellites distributed throughout telomeric and centromeric regions of autosomal and sex chromosomes, associated with other repetitive DNA sequences (Cioffi and Bertollo, 2012). Additionally, repetitive DNAs have an important role in speciation, differentiation of sex-specific regions, and promotion of biodiversity (Vicari et al., 2005; Cioffi et al., 2009; Sember et al., 2018). Therefore, here we analyzed the chromosomal location several microsatellites repeats to explore the intergenomic divergence at the chromosomal level in 12 Silurid species; the sampling resembles the one previously analyzed by Ditcharoen et al. (2019) with different cytogenetic methods. Indeed, our recent result provided new insights into the karyotype differentiation of this fish group, with a better understanding of the chromosomal organization of repetitive DNAs and uncovering chromosome homologies and differences among the studied species.

\section{Material and Methods}

Twelve silurid species were collected in the river basins of Thailand (Figure 1, Table 1). All individuals were deposited in the fish collection of the Cytogenetic Laboratory, Department of Biology, Faculty of Science (Khon Kaen University). The procedures followed ethical protocols and anesthesia was conducted with clove oil before euthanasia, as approved by the Institutional Animal Care and Use Committee of Khon Kaen University, based on the Ethics of Animal Experimentation of the National Research Council of Thailand IACUC-KKU-10/62.

Chromosomes were obtained by the classical airdrying method from kidney cells (Bertollo et al., 2015). The preparations were then dropped onto clean glass slides at 55 ${ }^{\circ} \mathrm{C}$ and stained with Giemsa 5\%. The hybridization procedure was taken under high stringency conditions (Yano et al., 2017), with six microsatellites as probes $\left[(\mathrm{CA})_{15}\right.$,

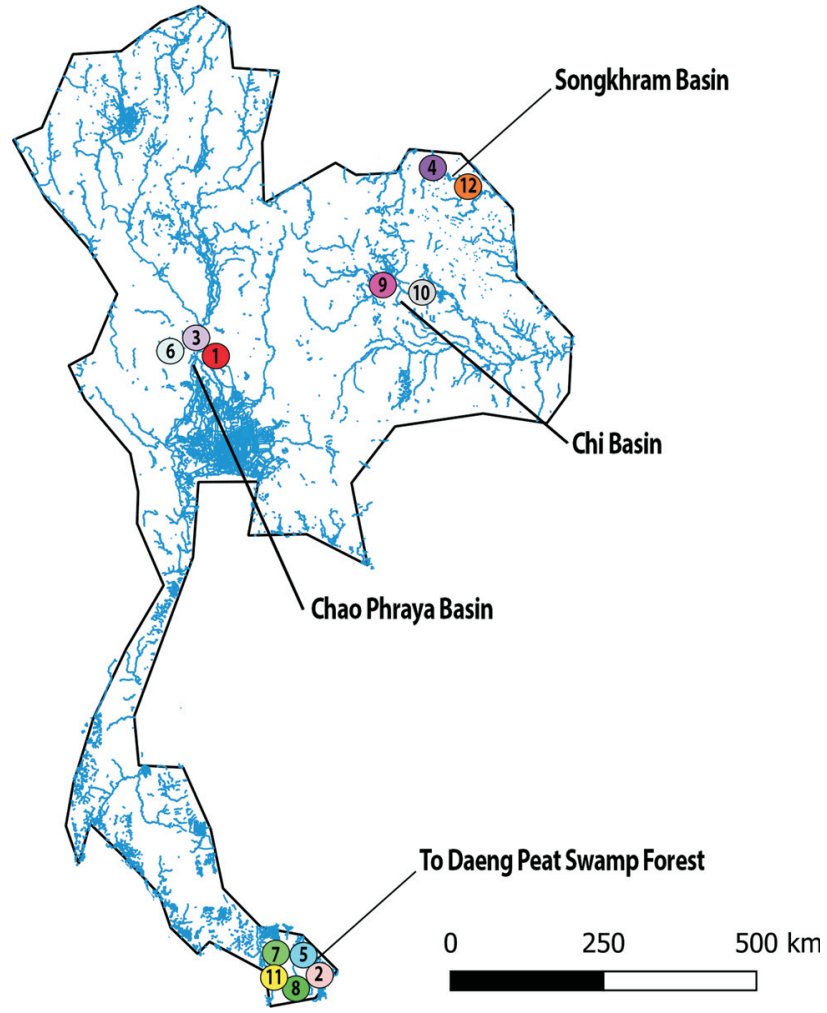

Figure 1 - Map of Thailand highlighting the collection sites of Silurid fishes studied herein. The numbers represent the different species sampled as shown in Table 1. The map was produced using the software QGis 3.4.4 (https:/qgis.org), Inkscape 0.92 (https://inkscape.org), and Adobe Photoshop CC 2015 (San Jose, CA, USA).

$(\mathrm{CAC})_{10},(\mathrm{CAT})_{10},(\mathrm{GC})_{15},(\mathrm{CGG})_{10},(\mathrm{~A})_{30}$ ] directly labeled with Cy-3 during the synthesis (Kubat et al., 2008). These sequences were selected from a pool of microsatellite repeats since they are commonly accumulated in several fish genomes (e.g. Nanda et al., 1990; Vanzela et al., 2002; Martins, 2007; Cioffi et al., 2011; Cioffi and Bertollo, 2012; Poltronieri et al., 2014; Cioffi et al., 2015; Pucci et al., 2016; Ráb et al., 2016; Sassi et al., 2019; Supiwong et al., 2019)

We performed at least three repetitions for each experiment and analyzed at least 30 metaphases per experiment to check the consistency of the results. Images were captured using an Olympus BX50 microscope (Olympus Corporation, Ishikawa, Japan) with CoolSNAP and processed using Image-Pro Plus 4.1 software (Media Cybernetics, Silver Spring, MD, USA).

\section{Results}

The microsatellite $(\mathrm{CA})_{15}$ revealed a telomeric pattern of accumulation in all chromosomes of all species (Figure 2), except for Kryptopterus geminus, where small telomeric signals occured in addition to strong centromeric ones in some other chromosomes. Similarly, the microsatellite $(\mathrm{CAC})_{10}$ also had a telomeric distribution on chromosomes (Figure 3), but again with an exception, in this case for Silurichthys phaiosoma which had only strong centromeric and telomeric signals in two acrocentric pairs, a larger and a 
Table 1 - Species analyzed, collection sites and the number of analyzed individuals (n).

\begin{tabular}{|c|c|c|}
\hline Species & Locality & $\mathrm{n}$ \\
\hline \multirow[t]{3}{*}{ 1. Belodontichthys truncatus } & Chao Phraya Basin & $04 \mathrm{f} ; 04 \mathrm{~m}$ \\
\hline & $14^{\circ} 52^{\prime} 17.3^{\prime \prime} \mathrm{N} 100^{\circ} 24^{\prime} 32.3^{\prime \prime} \mathrm{E}$ & \\
\hline & Ton Pho, Mueang Sing Buri District, Sing Buri & \\
\hline \multirow[t]{2}{*}{ 2. Kryptopterus bicirrhis } & To Daeng peat swamp forest & $07 \mathrm{f} ; 08 \mathrm{~m}$ \\
\hline & $6^{\circ} 04^{\prime} 34.0^{\prime \prime} \mathrm{N} 101^{\circ} 57^{\prime} 46.0^{\prime \prime} \mathrm{E}$ & \\
\hline \multirow[t]{3}{*}{ 3. Kryptopterus geminus } & Chao Phraya Basin & $08 \mathrm{f} ; 11 \mathrm{~m}$ \\
\hline & $14^{\circ} 52^{\prime} 17.3^{\prime \prime N} 100^{\circ} 24^{\prime} 32.3^{\prime \prime} \mathrm{E}$ & \\
\hline & Ton Pho, Mueang Sing Buri District, Sing Buri & \\
\hline \multirow[t]{2}{*}{ 4. Kryptopterus limpok } & Songkhram Basin & 07f; $10 \mathrm{~m}$ \\
\hline & $17^{\circ} 59^{\prime} 37.8^{\prime \prime} \mathrm{N} 103^{\circ} 26^{\prime} 54.2^{\prime \prime} \mathrm{E}$ & \\
\hline \multirow[t]{3}{*}{ 5. Kryptopterus macrocephalus } & To Daeng peat swamp forest & $06 \mathrm{f} ; 06 \mathrm{~m}$ \\
\hline & $6^{\circ} 04^{\prime} 34.0^{\prime \prime} \mathrm{N} 101^{\circ} 57^{\prime} 46.0^{\prime \prime} \mathrm{E}$ & \\
\hline & Puyo, Su-ngai Kolok District, Narathiwat & \\
\hline \multirow[t]{2}{*}{ 6. Micronema cheveyi } & $14^{\circ} 52^{\prime} 17.3^{\prime \prime N} 100^{\circ} 24^{\prime} 32.3^{\prime \prime} \mathrm{E}$ & 09f; $10 \mathrm{~m}$ \\
\hline & Ton Pho, Mueang Sing Buri District, Sing Buri & \\
\hline \multirow[t]{3}{*}{ 7. Ompok fumidus } & To Daeng peat swamp forest & $05 \mathrm{f} ; 07 \mathrm{~m}$ \\
\hline & $6^{\circ} 04^{\prime} 34.0^{\prime \prime} \mathrm{N} 101^{\circ} 57^{\prime} 46.0^{\prime \prime} \mathrm{E}$ & \\
\hline & Puyo, Su-ngai Kolok District, Narathiwat & \\
\hline \multirow[t]{3}{*}{ 8. Ompok siluroides } & To Daeng peat swamp forest & $04 \mathrm{f} ; 05 \mathrm{~m}$ \\
\hline & $6^{\circ} 04^{\prime} 34.0^{\prime \prime} \mathrm{N} 101^{\circ} 57^{\prime} 46.0^{\prime \prime} \mathrm{E}$ & \\
\hline & Puyo, Su-ngai Kolok District, Narathiwat & \\
\hline 9. Phalacronotus apogon & Chi Basin & 06f; $05 \mathrm{~m}$ \\
\hline \multirow[t]{3}{*}{ 10. Phalacronotus bleekeri } & Chi Basin & $07 \mathrm{f} ; 04 \mathrm{~m}$ \\
\hline & $16^{\circ} 13^{\prime} 35.5^{\prime \prime} \mathrm{N} 103^{\circ} 19^{\prime} 30.6^{\prime \prime E}$ & \\
\hline & Tha Khon Yang, Kantharawichai District, Maha Sarakham & \\
\hline \multirow[t]{3}{*}{ 11. Silurichthys phaiosoma } & To Daeng peat swamp forest & 04f; $06 \mathrm{~m}$ \\
\hline & $6^{\circ} 04^{\prime} 34.0^{\prime \prime} \mathrm{N} 101^{\circ} 57^{\prime} 46.0^{\prime \prime} \mathrm{E}$ & \\
\hline & Puyo, Su-ngai Kolok District, Narathiwat & \\
\hline \multirow[t]{3}{*}{ 12. Wallago attu } & Songkhram Basin & $03 \mathrm{f} ; 04 \mathrm{~m}$ \\
\hline & $17^{\circ} 59^{\prime} 37.8^{\prime \prime} \mathrm{N} 103^{\circ} 26^{\prime} 54.2^{\prime \prime} \mathrm{E}$ & \\
\hline & Dong Mo Thong Tai, Ban Muang District, Sakon & \\
\hline
\end{tabular}

f: female. m: male.

smaller one, respectively. However, separate scattered signals were also observed in several other chromosomes. As to the microsatellite $(\mathrm{CAT})_{10}$, all species have scattered telomeric hybridization signals (Figure 4). In turn, a very diverse distribution pattern was observed for the microsatellite $(\mathrm{GC})_{15}$ (Figure 5), where a dispersed distribution of small signals occurred in all chromosomes of Belodontichthys truncatus, Kryptopterus bicirrhis, K. geminus and K. macrocephalus. However, in Micronema cheveyi, Ompokfumidus, O. siluroides, Phalacronotus apogon, P. bleekeri, and Wallago attu, hybridization signals occurred in the centromeric and telomeric regions of almost half chromosomes of the complement. Yet, in Kryptopterus limpok and Silurichthys phaiosoma only a single pair of chromosomes were labeled in the centromeric region with such probe. The microsa- tellite $(\mathrm{CGG})_{10}$ had a very contrasting distribution compared to the other microsatellites. In this case, only one chromosome pair has telomeric signals in the $\mathrm{p}$ arms, in all twelve species analyzed (Figure 6 ). The microsatellite $(\mathrm{A})_{30}$ was the only one not found in any of the examined species (data not shown).

\section{Discussion}

The role of repetitive DNAs in the genome evolution has been documented for different fish groups (Cioffi et al., 2010; Cioffi and Bertollo, 2012; Terencio et al., 2013; Yano et al., 2014; Cioffi et al., 2015; Moraes et al., 2017, 2019; Sassi et al., 2019). Worthy of note is the great evolutionary diversification that Siluriformes fishes have experienced, es- 


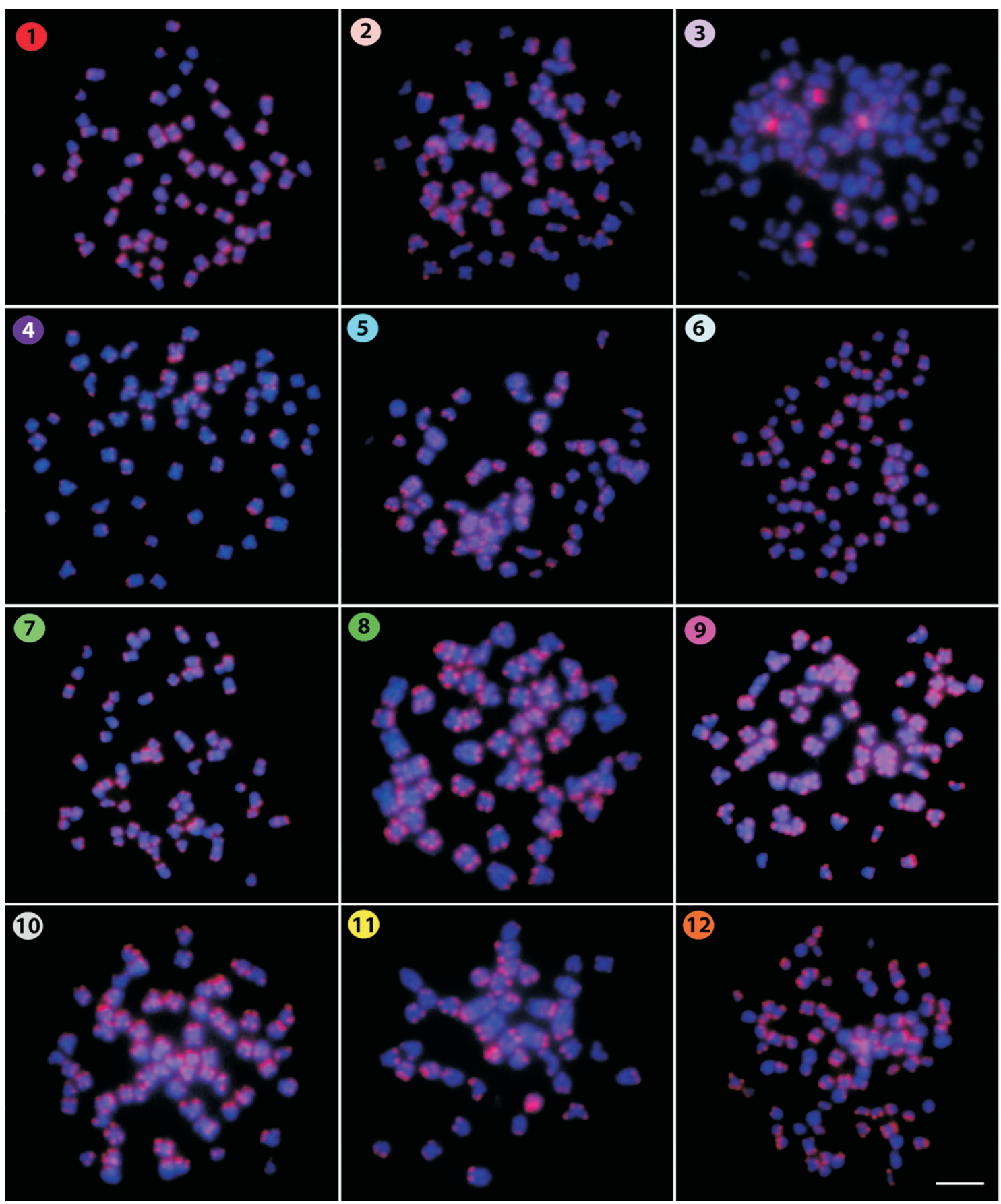

Figure 2 - Hybridization pattern of the (CA) ${ }_{15}$ microsatellite probe (in red) on metaphase chromosomes of Belodontichthys truncates (1); Kryptopterus bicirrhis (2); Kryptopterus geminus (3); Kryptopterus limpok (4); Kryptopterus macrocephalus (5); Micronema chevevi (6); Ompok fumidus (7); Ompok siluroides (8); Phalacronotus apogon (9); Phalacronotus bleekeri (10); Silurichthys phaiosoma (11) and Wallago attu (12). Scale bar $=5 \mu \mathrm{m}$.

pecially at the chromosomal level. Here, six mono-, bi- and tri-nucleotide microsatellite sequences were mapped on chromosomes of twelve Siluridae species. Except for $(\mathrm{A})_{30}$-, which was not found to occur in any of the analyzed species, all other probes generated ell visible hybridization patterns. However, highly divergent distributions have been found, even among congeneric species, as observed in Kryptopterus. Accordingly, this genus displays different 2n, karyotypes and an extensive variation of their repetitive DNA con- tent (Ditcharoen et al., 2019). On the other hand, the Phalacronotus species had a similar distribution pattern among chromosomes, probably linked to their chromosomal-conserved characteristics, since they share similarities in both karyotype and genome features (Ditcharoen et al., 2019). It is also remarkable that the same kind of microsatellite did not present the same pattern among silurids. Indeed, very different hybridization patterns for the same microsatellite occur among distinct species, as for the $(\mathrm{CA})_{15},(\mathrm{GC})_{15}$ and 


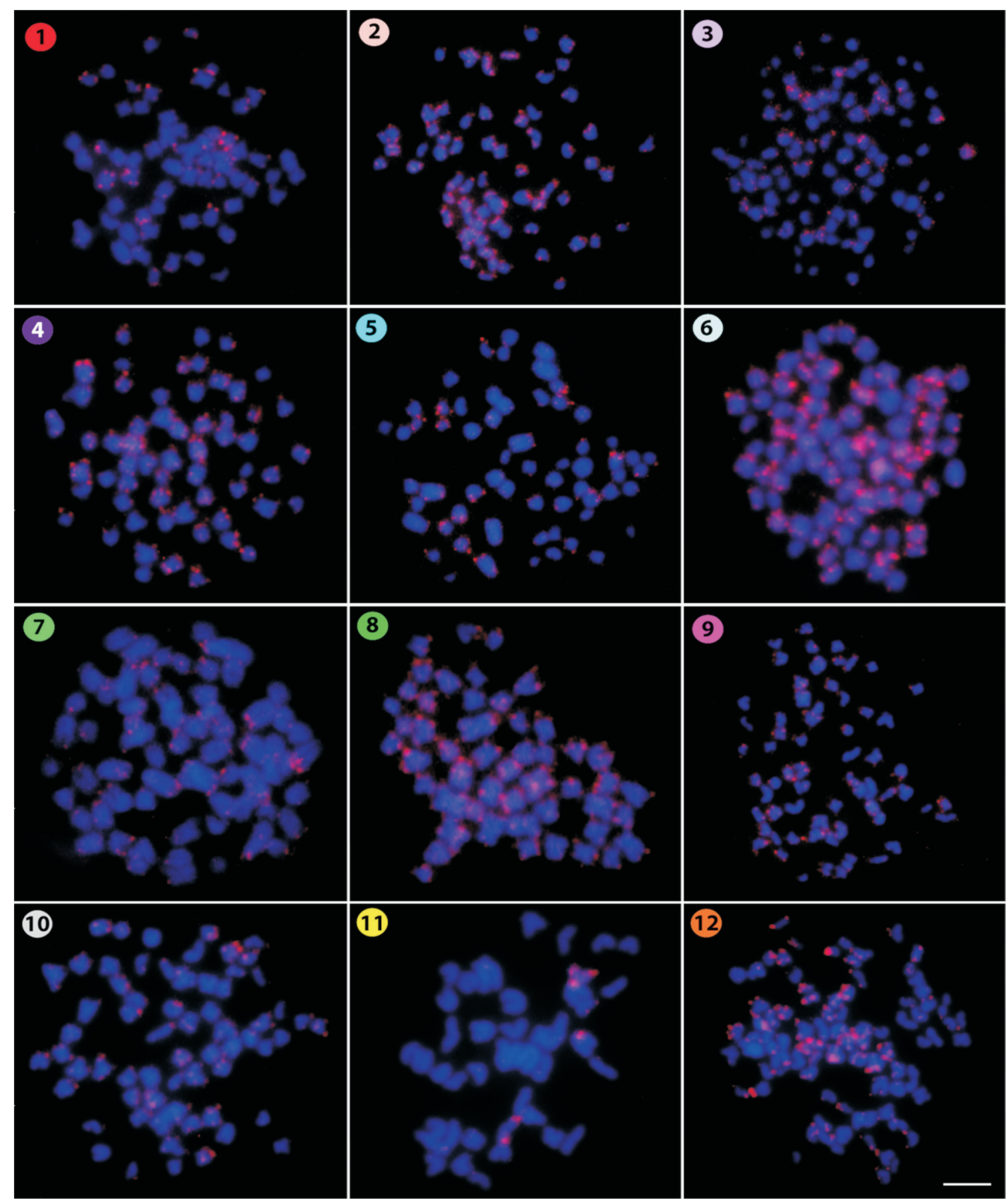

Figure 3 - Hybridization pattern of the (CAC) 10 microsatellite probe (in red) on metaphase plates of Belodontichthys truncates (1); Kryptopterus bicirrhis (2); Kryptopterus geminus (3); Kryptopterus limpok (4); Kryptopterus macrocephalus (5); Micronema chevevi (6); Ompok fumidus (7); Ompok siluroides (8); Phalacronotus apogon (9); Phalacronotus bleekeri (10); Silurichthys phaiosoma (11) and Wallago attu (12). Scale bar $=5 \mu \mathrm{m}$.

$(\mathrm{CAC})_{10}$ probes, for example, although mostly restricted to centromeric and telomeric regions, where a significant fraction of repetitive DNA is localized (Cioffi and Bertollo, 2012).

Additionally, the preferred telomeric and centromeric locations of microsatellites among silurids are, of course, of significance. For instance, this distribution pattern is found in some Siluriformes such as in the Neotropical catfishes Imparfinis schubarti (Heptapteridae), Steindachneridion scriptum (Pimelodidae), and Rineloricaria latirostris (Loricariidae) in which a remarkable accumulation of both $(\mathrm{GA})_{15}$ and $(\mathrm{A})_{30}$ microsatellites in telomeric regions occurs (Vanzela et al., 2002; Supiwong et al., 2014). A similar distribution is also present in the chromosomes of the zebrafish, Danio rerio, showing $(\mathrm{CA})_{\mathrm{n}}$ and $(\mathrm{GT})_{\mathrm{n}}$ repeats clustered in the centromeric and telomeric regions (Shimoda et al., 1999; Supiwong et al., 2014) and the wolffish, Hoplias malabaricus, where 12 different microsatellite repeats, including 


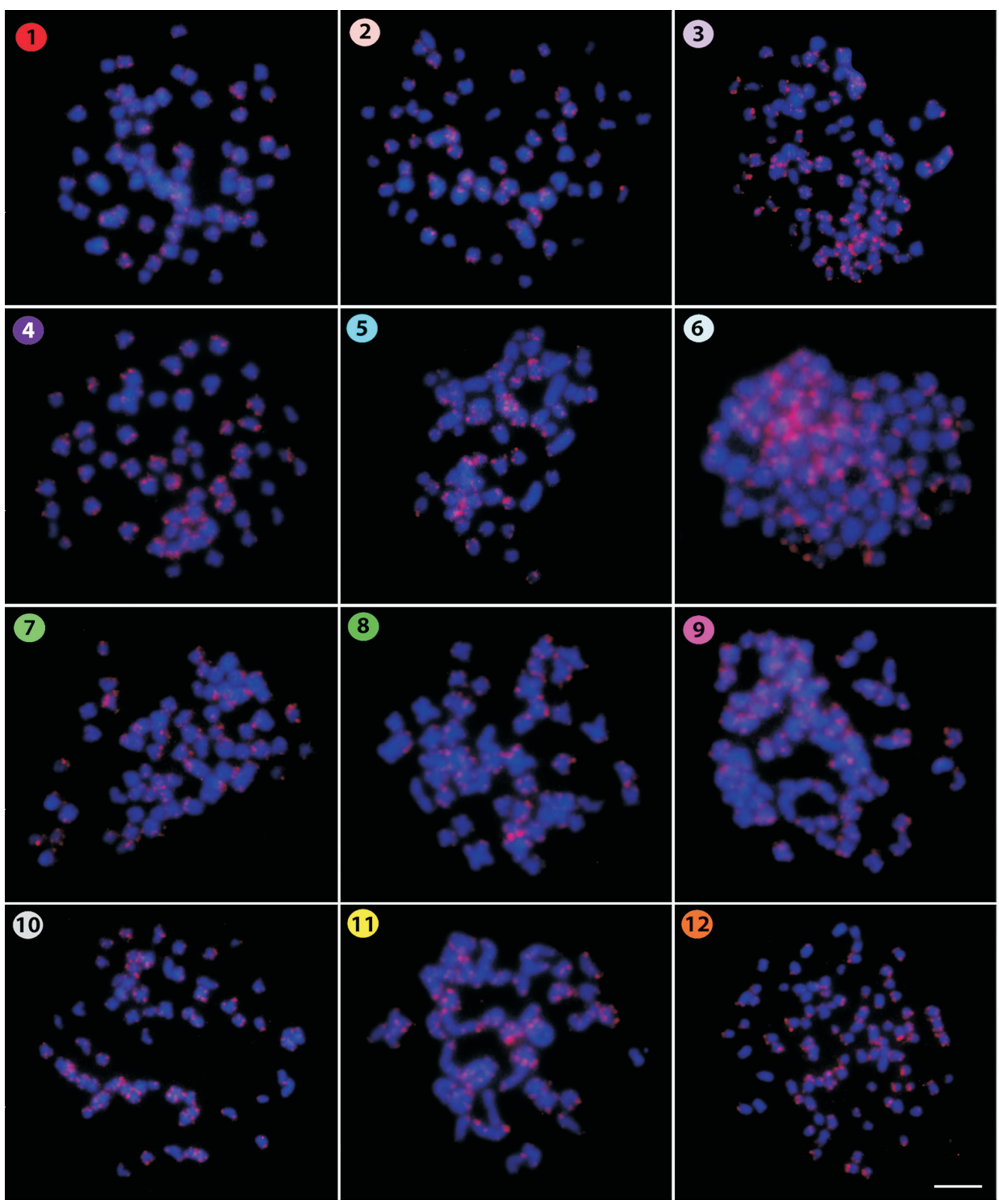

Figure 4 - Hybridization pattern of the (CAT) 10 microsatellite probe (in red) on metaphase plates of Belodontichthys truncates (1); Kryptopterus bicirrhis (2); Kryptopterus geminus (3); Kryptopterus limpok (4); Kryptopterus macrocephalus (5); Micronema chevevi (6); Ompok fumidus (7); Ompok siluroides (8); Phalacronotus apogon (9); Phalacronotus bleekeri (10); Silurichthys phaiosoma (11) and Wallago attu (12). Scale bar $=5 \mu \mathrm{m}$.

$(\mathrm{CA})_{15}$ and $(\mathrm{GA})_{15}$, showed strong hybridization signals at subtelomeric and heterochromatic regions of several autosomes, in addition to a strong accumulation on the sex chromosomes (Cioffi et al., 2011, Supiwong et al., 2014). In fact, for most of these species, the 18S rDNA repeats are found in the short arms of a single chromosome pair (Ditcharoen et al., 2019), and this region matches the position of the (CGG)n marks found in our experiments. Similarities of both microsatellite and ribosomal DNA location do not seem to be a rare event among fishes, as they are also found in other species, such as Lebiasina bimaculata (Sassi et al., 2019) and Hepsetus odoe (Carvalho et al., 2017), for example. Indeed, $\mathrm{G}+\mathrm{C}$ rich motifs are common in exons of all vertebrates (Chistiakov et al., 2006). Since higher recombination rates can be found near the telomeric region (Jensen-Seaman et al., 2004), the physical proximity of microsatellite and rDNA repeats could favor the evolutionary spreading of both sequences together, as triplet se- 

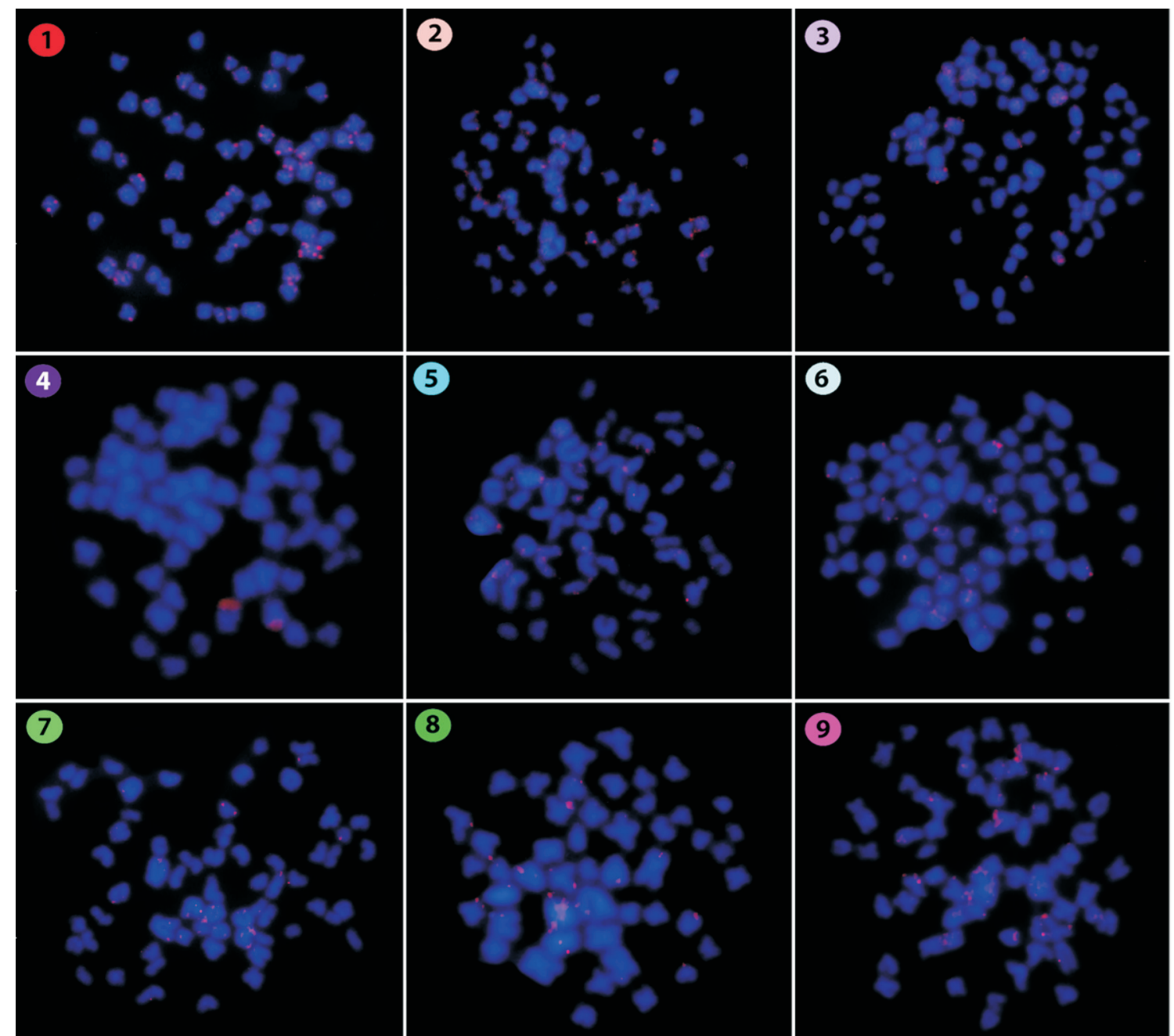

8

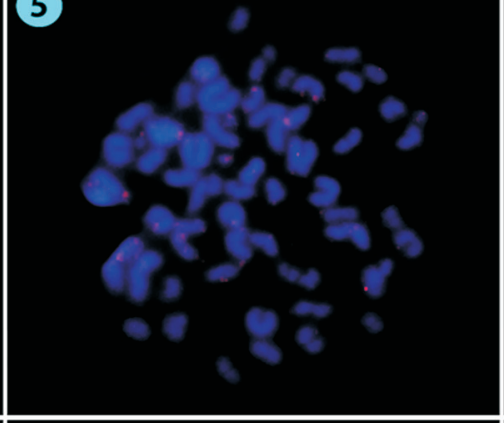

6
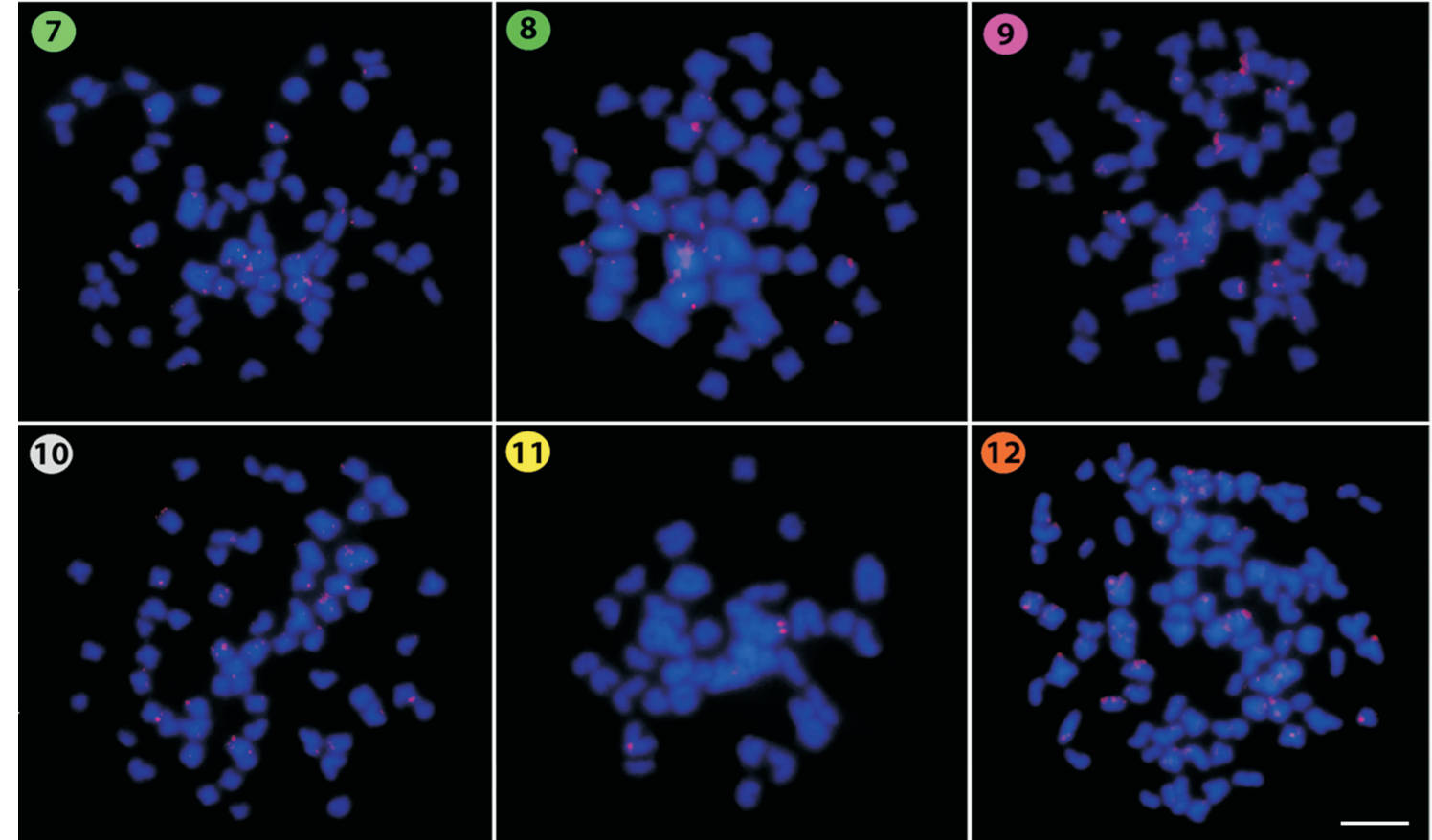

\section{1}

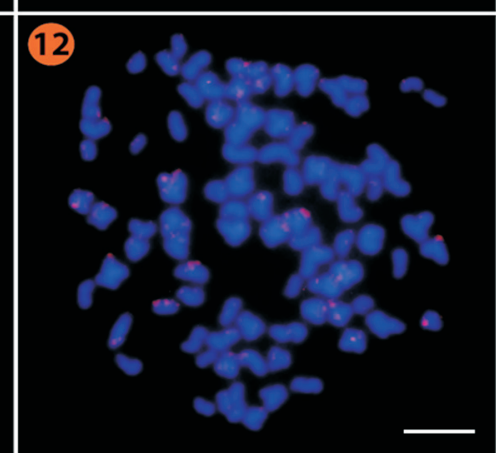

Figure 5 - Hybridization pattern of the (GC) ${ }_{15}$ microsatellite probe (in red) on metaphase plates of Belodontichthys truncates (1); Kryptopterus bicirrhis (2); Kryptopterus geminus (3); Kryptopterus limpok (4); Kryptopterus macrocephalus (5); Micronema chevevi (6); Ompok fumidus (7); Ompok siluroides (8); Phalacronotus apogon (9); Phalacronotus bleekeri (10); Silurichthys phaiosoma (11) and Wallago attu (12). Scale bar $=5 \mu \mathrm{m}$.

quences are particularly able to stabilize, by hairpin, some alternative structures generated from DNA polymerase slippage (Sinden, 1999). Reinforcing the above considerations, Silurichthys phaiosoma has a very particular distribution of the $(\mathrm{CAC}) \mathrm{n}$ repeats, accumulated in the centromeric and telomeric regions of two acrocentric pairs, respectively. Accordingly, this species also presents a unique pattern of $5 \mathrm{~S}$ rDNA distribution concerning the other silurids, with the spreading of multiple loci in the karyotype. Besides, a $5 \mathrm{~S}$
rDNA site is found in the telomeric region of the long arms of the $18^{\text {th }}$ chromosome pair (Ditcharoen et al., 2019), the same one that harbors a conspicuous (CAC)n site.

It is known that eukaryotic centromeres are usually composed of AT-rich DNA (Blackburn and Szostak, 1984) and is commonly rich in heterochromatin, with a complex composition of several repetitive in tandem DNAs (LópezFlorez and Garrido-Ramos, 2012). Although (AC)n represents the most common microsatellites (Chistiakov et al., 


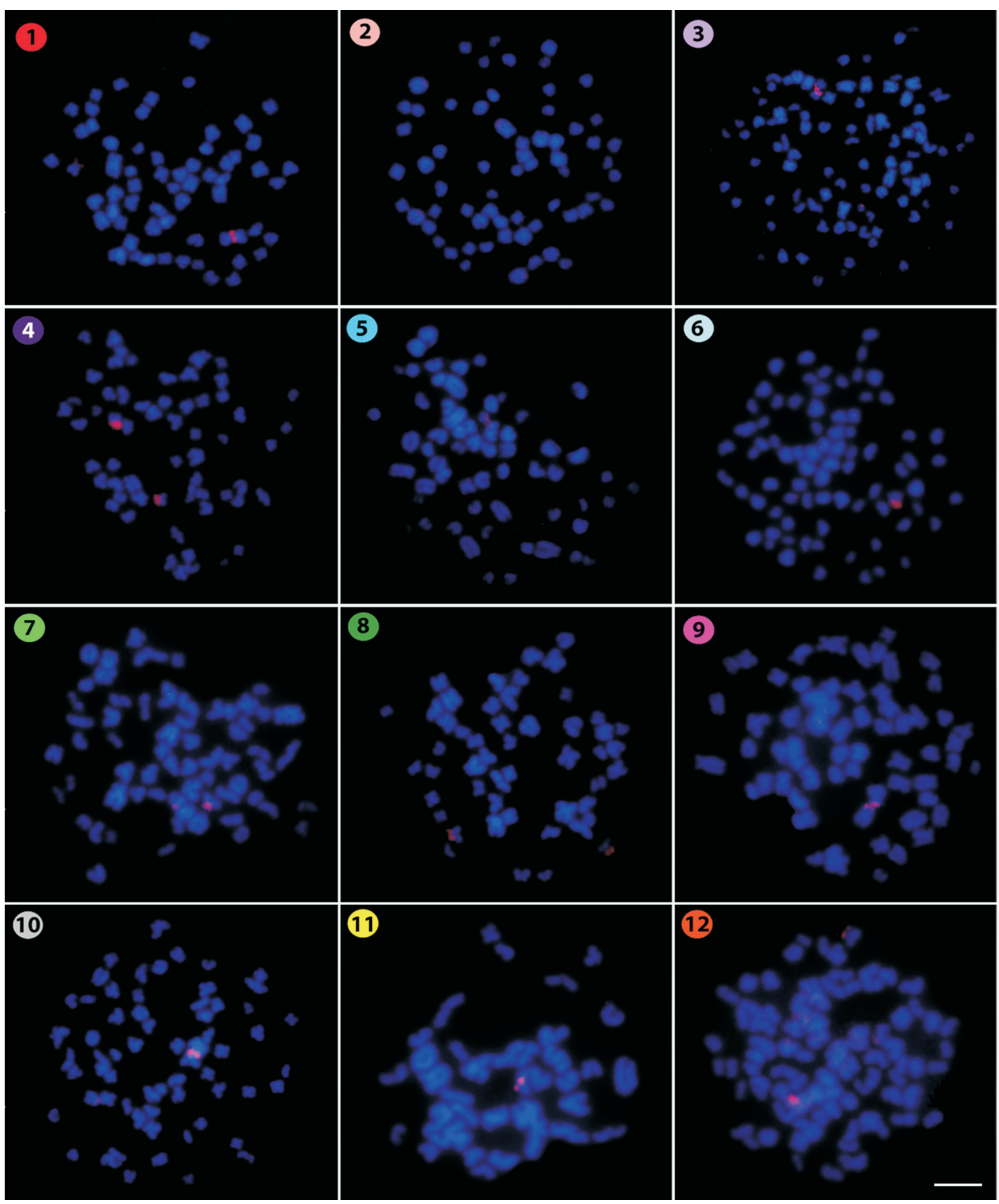

Figure 6 - Hybridization pattern of the (CGG) ${ }_{10}$ microsatellite probe (in red) on metaphase plates of Belodontichthys truncates (1); Kryptopterus bicirrhis (2); Kryptopterus geminus (3); Kryptopterus limpok (4); Kryptopterus macrocephalus (5); Micronema chevevi (6); Ompok fumidus (7); Ompok siluroides (8); Phalacronotus apogon (9); Phalacronotus bleekeri (10); Silurichthys phaiosoma (11) and Wallago attu (12). Scale bar $=5 \mu \mathrm{m}$.

2006), it is noteworthy the predominance of (GC) rich microsatellites in the heterochromatic regions of fishes (Artoni and Bertollo, 1999; Kavalco et al., 2005; Oliveira et al., 2015; Sassi et al., 2019). Accordingly, at least six Siluridae species now investigated (Micronema cheveyi, Ompok fumidus, O. siluroides, Phalacronotus apogon, P. bleekeri, and Wallago attu) have (GC)n pericentromeric signals for almost half chromosomes, in addition to other species, like Kryptopterus limpok and Silurichthys phaiosoma, that have a single labeled chromosome pair but also in this same region. These findings suggest an association and accumulation of such sequences in this relevant chromosome region, as observed in several other fish species (reviewed in Cioffi and Bertollo, 2012).

Repetitive DNA sequences could act as primary driving forces in speciation (reviewed in Biémont and Vieira, 2006). These sequences are highly associated with heterochromatic regions, thus contributing to gene activation and 
structural maintenance of chromosomes (Dernburg et al., 1996). Therefore, great variations in the amount and position of these sequences could create fertility barriers by fostering the occurrence of chromosomal rearrangements (Cioffi and Bertollo, 2012). Indeed, the distribution of microsatellite motifs in fish genomes could be biased to some specific noncoding regions, as found in the Asian swamp eel Monopterus albus (Li et al., 2017). Additionally, closely related fish species involved in recent speciation events could present a differential pattern in the distribution and quantity of microsatellite sequences on chromosomes, as demonstrated for naked catfishes (Supiwong et al., 2014), channid fishes (Cioffi et al., 2015) and Siluridae species in this paper.

Our results indicate that microsatellite sequences have divergent patterns of distribution and accumulation among Siluridae fishes, probably fostering the chromosomal differentiation and biodiversity in this fish family. Indeed, they are especially present in especific chromosome locations, such as the centromeric and telomeric regions, precisely the ones that are associated with several kinds of chromosomal rearrangements. In addition to their probable roles during chromosomal diversification, it is also highlighted that microsatellites can have a close association with other important classes of repetitive sequences, like ribosomal DNAs. This association can represent a good strategy for increasing biodiversity, facilitating a combined distribution of distinct DNA sequences along with the evolutionary divergence.

\section{Acknowledgments}

This research project was supported by the Thailand Research Fund (TRF) under the Royal Golden Jubilee (RGJ) Ph.D. Program grant No. PHD/0165/2559 and Unit of Excellence 2019 on Biodiversity and Natural Resources Management, University of Phayao (UoE62005). MBC was supported by Conselho Nacional de Desenvolvimento Científico e Tecnológico (CNPq) (Proc. Nos. 401962/2016-4 and 302449/2018-3), Fundação de Amparo à Pesquisa do Estado de São Paulo (FAPESP) (Proc. No. 2018/22033-1), and CAPES/Alexander von HumboldtStiftung (Proc. No. 88881.136128/2017-01).

\section{Conflict of interest}

The authors declare that no conflict of interest could be perceived as prejudicial to the impartiality of the reported research.

\section{Authors Contributions}

LACB, TL, AT and MBC conceived and the study; $\mathrm{SD}$, FMCC, PS, WS, CS and MBC conducted the experiments; SD, FMCC, WFM, TL and MBC analyzed the data; SD, FMCC, LACB, WFM, TL, PS, AT, WS, CS and MBC wrote the manuscript, authors read and approved the final version.

\section{References}

Artoni RF and Bertollo LAC (1999) Nature and distribution of constitutive heterochromatin in fishes, genus Hypostomus (Loricariidae). Genetica 106:209-214.

Berg LS (1964) Freshwater fishes of the U.S.S.R. and adjacent countries. 4nd edition. Israel Program for Scientific Translations Ltd, Jerusalem.

Bertollo LAC, Cioffi MB and Moreira-Filho O (2015) Direct chromosome preparation from freshwater teleost fishes. In: Ozouf-Costaz C, Pisano E, Foresti F, Toledo LFA (eds) Fish cytogenetic techniques: Ray-Fin fishes and chondrichthyans. 2nd edition. CRC Press, Boca Raton, pp 21-26.

Biémont C and Vieira C (2006) Junk DNA as an evolutionary force. Nature 443:521.

Blackburn EH and Szostak JW (1984) The molecular structure of centromeres and telomeres. Annu Rev Biochem 53:163-194.

Bornbusch AH (1995) Phylogenetic relationships within the Eurasian catfish family Siluridae (Pisces: Siluriformes), with comments on generic validities and biogeography. Zool J Linn Soc 115:1-46.

Carvalho PC, Oliveira EA, Bertollo LA, Yano CF, Oliveira C, Decru E, Jegede OI, Hatanaka T, Liehr T, Al-Rikabi ABH et al. (2017). First chromosomal analysis in Hepsetidae (Actinopterygii, Characiformes): Insights into relationship between African and Neotropical fish groups. Front Genet 8:203.

Chapman FA, Fitz-Coy SA, Thunberg EM and Adams CM (1997) United States of America trade in ornamental fish. J World Aquacult Soc 28:1-10.

Chistiakov DA, Hellemans B and Volckaert FA (2006) Microsatellites and their genomic distribution, evolution, function and applications: a review with special reference to fish genetics. Aquaculture 255:1-29.

Cioffi MB, Martins C and Bertollo LAC (2009) Comparative chromosome mapping of repetitive sequences. Implications for genomic evolution in the fish Hoplias malabaricus. BMC Genet 10:34.

Cioffi MB, Martins C and Bertollo LAC (2010) Chromosome spreading of associated transposable elements and ribosomal DNA in the fish Erythrinus erythrinus. Implications for genome change and karyoevolution in fish. BMC Evol Biol 10:271.

Cioffi MB, Kejnovsky E and Bertollo LAC (2011) The chromosomal distribution of microsatellite repeats in the genome of the wolf fish Hoplias malabaricus, focusing on the sex chromosomes. Cytogenet Genome Res 132:289-296.

Cioffi MB and Bertollo LAC (2012) Chromosomal distribution and evolution of repetitive DNAs in fish. In: Garrido-Ramos MA (ed) Repetitive DNA. Karger Publishers, Basel, vol. 7, pp 197-221.

Cioffi MB, Bertollo LAC, Villa MA, Oliveira EA, Tanomtong A, Yano CF, Supiwong W and Chaveerach A (2015) Genomic organization of repetitive DNA elements and its implications for the chromosomal evolution of channid fishes (Actinopterygii, Perciformes). PLoS One 10:e0130199.

Dernburg AF, Sedat JW and Hawley RS (1996) Direct evidence of a role for heterochromatin in meiotic chromosome segregation. Cell 86:135-146

Ditcharoen S, Bertollo LAC, Ráb P, Hnátková E, Molina WF, Liehr $\mathrm{T}$, Tanomtong A, Triantaphyllidis C, Ozouf-Costaz C, Tongnunui S et al. (2019) Genomic organization of repetitive DNA elements and extensive karyotype diversity of silurid cat- 
fishes (Teleostei: Siluriformes): A comparative cytogenetic approach. Int J Mol Sci 20:3545.

Donsakul T and Magtoon W (1996) A chromosome study on four species of silurid fishes, Wallago miostoma, $W$. attu, $W$. dinema and Kryptopterus bicirihis. In: Proceedings of the $34^{\text {th }}$ Kasetsart University Annual Conference, Bangkok, Thailand.

Hardman M (2005) The phylogenetic relationships among nondiplomystid catfishes as inferred from mitochondrial cytochrome b sequences; the search for the ictalurid sister taxon (Otophysi: Siluriformes). Mol Phylogenet Evol 37:700-720.

Jensen-Seaman MI, Furey TS, Payseur BA, Lu Y, Roskin KM, Chen CF, Thomas MA, Haussler D and Jacob HJ (2004) Comparative recombination rates in the rat, mouse, and human genomes. Genome Res 14:528-538.

Kappas I, Vittas S, Pantzartzi CN and Drosopoulou E (2016) A time-calibrated mitogenome phylogeny of catfish (Teleostei: Siluriformes). PLoS One 11:1-16.

Kavalco KF, Pazza R, Bertollo LAC and Moreira-Filho O (2005) Karyotypic diversity and evolution of Loricariidae (Pisces, Siluriformes). Heredity 94:180.

Kottelat M (2013). The fishes of the inland waters of Southeast Asia: a catalogue and core bibliography of the fishes known to occur in freshwaters, mangroves and estuaries. Raffles B Zool 27:1-663.

Li Z, Chen F, Huang C, Zheng W, Yu C, Cheng H and Rongjia Zhou R (2017) Genome-wide mapping and characterization of microsatellites in the swamp eel genome. Sci Rep 7:3157.

Linhart O, etch L, varc J, Rodina M, Audebert JP, Grecu J and Billard R (2002) The culture of the European catfish, Silurus glanis, in the Czech Republic and in France. Aquat Living Resour 15:139-144.

López-Flores I and Garrido-Ramos MA (2012) The repetitive DNA content of eukaryotic genomes. In: Garrido-Ramos MA (ed) Repetitive DNA. Karger Publishers, Basel, vol. 7, pp 1-28.

Martins C (2007) Chromosomes and repetitive DNAs: A contribution to the knowledge of fish genome. In: Pisano E, OzoufCostaz C, Foresti F and Kapoor BG (eds) Fish Cytogenetics. Science Publishers, Enfield, pp 421-452.

Moraes RLR, Bertollo LAC, Marinho MMF, Yano CF, Hatanaka T, Barby FF, Troy WP and Cioffi MB (2017) Evolutionary relationships and cytotaxonomy considerations in the genus Phyrrhulina (Characiformes, Lebiasinidae). Zebrafish 14:1-11.

Moraes RLR, Sember A, Bertollo LAC, de Oliveira EA, Ráb P, Hatanaka T, Marinho MMF, Liehr T, Al-Rikabi ABH, Feldberg E, Viana PF and Cioffi MB (2019) Comparative cytogenetics and neo-Y formation in small-sized fish species of the genus Pyrrhulina (Characiformes, Lebiasinidae). Front Genet 10:678.

Nanda I, Feichtinger W, Schmid M, Schröder JH, Zischler H and Epplen JC (1990) Simple repetititve sequences are associated with differentiation of the sex chromosomes in the guppy fish. J Mol Evol 30:456-462.

Ng PKL and Lim KKP (1992) The conservation status of the Nee Soon freshwater swamp forest of Singapore. Aquat Conserv 2:255-266.

$\mathrm{Ng} \mathrm{HH}$ and Ng PKL (1998) A revision of the South-east Asian catfish genus Silurichthys. J Fish Biol 52:291-333.

Ng PKL, Tay JB and Lim KKP (1994) Diversity and conservation of blackwater fishes in Peninsula Malaysia, particularly in the North Selangor peat swamp forest. Hydrobiologia 285:203218.

Oliveira EA, Bertollo LAC, Yano CF, Liehr T and Cioffi MB (2015) Comparative cytogenetics in the genus Hoplias (Characi- formes, Erythrinidae) highlights contrasting karyotype evolution among congeneric species. Mol Cytogenet 8:56.

Poltronieri J, Marquioni V, Bertollo LAC, Kejnovsky E, Molina WF, Liehr T and Cioffi MB (2014) Comparative chromosomal mapping of microsatellites in Leporinus species (Characiformes, Anostomidae): Unequeal accumulation on the $\mathrm{W}$ chromosomes. Cytogenet Genome Res 142:40-45.

Pucci MB, Barbosa P, Nogaroto V, Almeida MC, Artoni RF, Scacchetti PC, Pansonato-Alves JC, Foresti F, Moreira-Filho $\mathrm{O}$ and Vicari MR (2016) Chromosomal spreading of microsatellite nad (TTAGGG)n sequences in the Characidium zebra and C. gomesi genomes (Characiformes: Crenuchidae). Cytogenet Genome Res 149:182-190.

Ráb P, Yano CF, Lavoué S, Jegede OI, Bertollo LAC, Ezaz T, Majtánová Z, de Oliveira EA and Cioffi MB (2016) Karyotype and mapping of repetitive DNAs in the African butterfly fish Pantodon buchholzi, the sole species of the family pantodontidae .Cytogenet Genome Res 149:312-320.

Sassi FMC, Oliveira EAD, Bertollo LAC, Nirchio M, Hatanaka T, Marinho MMF, Moreira-Filho O, Aroutiounian R, Liehr T, Al-Rikabi ABH et al. (2019) Chromosomal evolution and evolutionary relationships of Lebiasina species (Characiformes, Lebiasinidae). Int J Mol Sci 20:2944.

Schueler MG, Higgins AW, Rudd MK, Gustashaw K and Willard HF (2001) Genomic and genetic definition of a functional human centromere. Science 294:109-115.

Sember A, Bertollo LAC, Ráb P, Yano CF, Hatanaka T, de Oliveira EA and Cioffi MB (2018) Sex chromosome evolution and genomic divergence in the Fish Hoplias malabaricus (Characiformes, Erythrinidae). Front Genet 9:1-12.

Shimoda N, Knapik EW, Ziniti J, Sim C, Yamada E, Kaplan S, Jackson D, de Sauvage F, Jacob H and Fishman MC (1999) Zebrafish genetic map with 200 microsatellite markers. Genomics 58:219-232.

Sinden RR (1999) Biological implications of the DNA structures associated with disease-causing triplet repeats. Am J Hum Genet 64:346-353.

Sullivan JP, Lundberg JG and Hardman M (2006) A phylogenetic analysis of the major groups of catfishes (Teleostei: Siluriformes) using rag1 and rag2 nuclear gene sequences. Mol Phylogenet Evol 41:636-662.

Supiwong W, Liehr T, Cioffi MB, Chaveerach A, Kosyakova N, Pinthong K, Tanee T and Tanomtong A (2014) Chromosomal evolution in naked catfishes (Bagridae, Siluriformes): A comparative chromosome mapping study. Zool Anz 253:316-320.

Supiwong W, Pinthong K, Seetapan K, Saenjundaeng P, Bertollo LAC, Oliveira EA, Yano CF, Liehr T, Phimphan S, Tanomtong A, et al. (2019) Karyotype diversity and evolutionary trends in the Asian swamp eel Monopterus albus (Synbranchiformes, Synbranchidae): a case of chromosomal speciation? BMC Evol Biol 19:73.

Tautz D and Renz M (1984) Simple sequences are ubiquitous repetitive components of eukaryotic genomes. Nucleic Acids Res 12:4127-4138.

Terencio ML, Schneider CH, Gross MC, Vicari MR, Farias IP, Passos KB and Feldberg E (2013) Evolutionary dynamics of repetitive DNA in Semaprochilodus (Characiformes, Prochilodontidae): a fish model for sex chromosome differentiation. Sex Dev 7:325-333.

Vanzela ALL, Swarça AC, Dias AL, Stolf R, Ruas PM, Ruas CF, Sbalqueiro IJ and Giuliano-Caetano L (2002) Differential distribution of (GA)9+C microsatellite on chromosomes of some animal and plant species. Cytologia 67:9-13. 
Verma J, Lakra WS, Kushwaha B, Sirajuddin M, Nagpure NS and Kumar R (2011) Characterization of two freshwater silurid catfish using conventional and molecular cytogenetic techniques. J Genet 90:319-322.

Vicari MR, Artoni RF and Bertollo LAC (2005) Comparative cytogenetics of Hoplias malabaricus (Pisces, Erythrinidae): A population analysis in adjacent hydrographic basins. Genet Mol Biol 28:103-110.

Yano CF, Bertollo LAC and Cioffi MB (2017) Fish-FISH: molecular cytogenetics in fish species. In: Liehr T (ed) Fluorescence in situ hybridization (FISH). 2nd edition. Springer-Verlag, Berlin, pp 429-443.

Yano CF, Poltronieri J, Bertollo LAC, Artoni RF, Liehr T and Cioffi MB (2014) Chromosomal mapping of repetitive DNAs in Triportheus trifurcatus (Characidae, Characiformes): in- sights into the differentiation of the $\mathrm{Z}$ and $\mathrm{W}$ chromosomes. PLoS One 9:e90946.

\section{Internet Resources}

Fricke R, Eschmeyer WN, and van der Laan R (2019). Catalog of fishes: genera, species, references: California Academy of Sciences, http://researcharchive.calacademy.org/research/ichthyology/catalog/SpeciesByFamily.asp (November 03, 2019).

Associate Editor: Maria Jose de Jesus Silva

License information: This is an open-access article distributed under the terms of the Creative Commons Attribution License (type CC-BY), which permits unrestricted use, distribution and reproduction in any medium, provided the original article is properly cited. 